\title{
Elizabethkingia meningoceptica
}

National Cancer Institute

\section{Source}

National Cancer Institute. Elizabethkingia meningoceptica. NCI Thesaurus. Code C86353.

A species of obligately aerobic, Gram negative, rod shaped bacterium in the phylum Bacteroidetes. This species is catalase, oxidase and indole positive, does not reduce nitrate, urease negative and hydrolyzes esculin. E. meningoceptica is pathogenic, being the causative agent of mening itis in newborns. 